\title{
Building work-related knowledge about examination invigilation through reflective journaling
}

\author{
Mark Minott \\ Graduate School of Education, University of Bristol, Bristol, UK
}

\begin{abstract}
Purpose - The purpose of the self-study is two-fold: first, to aid in redressing the lack of attention given to the professional development i.e., the building of practical or work-related knowledge of examination invigilators and second, to forward the idea that engaging the examination invigilation process reflectively is an effective form of self-directed professional development.
\end{abstract}

Design/methodology/approach - The report uses reflective journaling based on Minott (2017) reflective approach to teaching practicum debriefing strategy to show the practical or work-related knowledge built by the author.

Findings - The report shows how the author built practical or work-related knowledge about critical aspects of the invigilation process: adaptability/flexibility, leading humanely and "thinking on your feet"/ reflection-in-action.

Originality/value - This paper shows (through a critical discussion of the literature, coupled with the author's personal professional experiences displayed in reflective journal entries) that an attitude of self-directed inquiry combined with reflective journaling can enable professional development i.e. the development of practical or work-related knowledge.

Keywords Invigilation, Proctor, Examination, Further education, Higher education, Reflective journaling, Self-directed professional development, Examination Invigilation

Paper type Viewpoint

\section{Introduction}

The purpose of this self-study was two-fold. First, to aid in redressing the lack of attention given to the professional development of examination invigilators and second, to show (through a critical discussion of the literature coupled with personal professional experiences displayed in reflective journal entries) that an attitude of self-directed inquiry combined with reflective journaling enable professional development (i.e. the development of practical or work-related knowledge needed to function in a role as a further and higher-education senior examination invigilator).

Lack of attention given to the professional development of examination invigilators and the general role of - examination invigilators (the UK), proctors (the USA) i.e. people with the tasks of ensuring that examinations are carried out according to rules set by examination boards and or various schools and universities governing bodies - can be seen in the fact that a search of 65 databases via the university of Bristol library using the following search terms and parameters - exam or examination and invigilation or invigilator(s) or proctor and professional development, year 2000-2019 - returned a total of 28 "hits." None mentioned invigilation or addressed facets of the invigilators' role and professional development and none included data emerging from research with actual invigilators. 
In this paper, work-related knowledge is defined as that which is built upon the job as the invigilator grapples with the challenges of leading examination invigilation teams and seek to refine professional practice. It also forms a large part of the author's knowledge base that shapes his actions and how he plan and carry out his role. Through engaging the examination invigilation process reflectively - enacted through reflective journaling - the author built work-related knowledge about critical aspects of the invigilation process: adaptability/flexibility, leading humanely and "thinking on your feet"/reflection-in-action.

This report commences with a critical discussion of self-directed professional development, its benefits and challenges and the connection between self-directed professional development and reflective journaling. The report ends with a critical discussion and display of how, via engaging the examination invigilation process reflectively - enacted through reflective journaling - the author built practical or workrelated knowledge in the three areas of professional practice outlined above.

\section{Self-directed professional development: benefits and challenges}

The thoughts of Villegas-Reimers (2003) underpinned the self-study and guided thinking about professional development. The writers state that knowledge, which results in improved teaching and learning, is gained by reflecting on practice and using a process of inquiry in one's working environment. Chitpin and Evers (2005) refer to this process as building practical or work-related knowledge, which requires a focus on problems at hand and making a conscious habit of thinking of possible solutions. Bezzina and Camilleri (2001) believe that ultimately professional development depends very much on the personal initiative of each individual. This thought is summed up in the term: "self-directed professional development." But what exactly is self-directed professional development and what are the benefits for those willing to apply this mode of development?

\section{Self-directed professional development}

Scrutiny of a number of definitions of the term "professional development" - for example, Speck and Knipe (2005), Golding and Gray (2006) and Harvey et al. (2005) - reveals that it refers primarily to updating or building up work-related knowledge that enables individuals to function effectively in their chosen profession. Another common characteristic of these definitions is their focus on the individual and his or her role in the development process. This is highlighted by Villegas-Reimers (2003) when the writer states: "Professional development, in a broad sense, refers to the development of a person." Tigelaar et al. (2005) extend this thought by stating that individuals are actively constructing their own workrelated knowledge by interpreting events on the basis of existing knowledge, beliefs and dispositions and by learning from experiences. While one can agree with Tigelaar et al. (2005), if the process they outline is to be effective then reflection must be an integral aspect, for reflection is a "tool" that teachers and other professionals such as nurses use to develop the capacity to learn from their experiences and to integrate what is learnt in various aspects of practice (Shulman and Shulman, 2004).

Another thing that can be inferred from the ideas of Villegas-Reimers (2003) and Tigelaar et al. (2005) is the fact that updating or building work-related knowledge (i.e. professional development) requires an attitude of inquiry and engagement in self-assessment. This occurrence is aptly defined by Brown et al. (2001) as self-directed professional development, which involves the shifting of the responsibility for the development of work-related knowledge away from preceptors to the individual. However, adopting an attitude of inquiry and engaging with self-assessment is not without its challenges; for example, there must be the desire for and a personal decision made by individuals to adopt this way of thinking. 
Inevitably, there will be some who will not see the necessity for doing so and rely solely on formal professional development exercises for their professional growth. Further, a lack of concern or an unwillingness to adopt an attitude of inquiry and engaging with selfassessment can also be reinforced if the individual works in an institution where the ethos (i.e. the fundamental and distinctive characteristics of the institution) does not encourage ' this way of thinking.

While the foregone discussion and definition of self-directed professional development hinted at its benefits - for example, enabling individuals to function effectively in their chosen profession, there are other ways that one can benefit. For example, it helps to reduce incompetence, addresses individual needs and encourages a high standard of personal professional performance. These benefits and some challenges are discussed in the next section.

\section{Benefits and challenge of self-directed professional development}

Brown et al. (2001) suggest that self-directed professional development is necessary for preventing persons from becoming less competent as practitioners. Brown et al. (2001) argue for practitioners to be committed to an attitude of personal growth and life-long learning. While Brown et al. (2001) spoke specifically of persons in pharmaceutical care, their opinions are equally applicable to examination invigilators and those who lead invigilation teams because information, procedure and examination media (computerbased or online examination) have expanded. These require keeping abreast of changes and the continued development of knowledge in the area.

Another benefit of self-directed professional development is that it can be used to address individual needs. This is even more empowering than the more usual in-service mode of development. This thought is echoed by Grootenboer (2009), who concluded that participants in his study were unanimous in proclaiming that self-directed professional development was their preferred mode for development or building work-related knowledge because it met their personal needs for professional growth. Presently in the UK, it seems professional development of examination invigilators is confined to times of training just before a period of examination. Such training, however, focuses on maintaining examination procedures (Minott, 2018). The thoughts of Borko (2004) about teachers' professional development are also applicable to examination invigilator. The writer bemoans the state of teachers' professional development when he states that despite the recognition of its importance, the professional development currently available to them is woefully inadequate and intellectually superficial.

Alsop (2000) points out other advantages of self-directed professional development when the writer states that it encourages a high standard of personal professional performance, demonstrates a commitment to best practice, increases job satisfaction, expands areas of expertise and improves personal efficacy. Grootenboer (2009) agrees with these and adds that it allows the individual to direct their own development, to improve their confidence and provides opportunities to think about one's own practice.

From the discussion so far, one can see obvious benefits to self-directed professional development. However, Craig (1999) states that it can be challenging when an individual is not accustomed to being self-directed or is uncomfortable setting and adhering to personal objectives and would prefer to be given instruction by an instructor and may need the synergism of a group. An individual with this disposition is likely to have a preference for more formal professional development modes such as workshops, conferences and seminars. Having said this, it is also likely that, with appropriate mentoring and an institutional ethos that encourages self-directed professional development, such an 
individual could be encouraged to see and appreciate the value of engaging in this mode of professional development. The benefits of self-directed professional development do seem to outweigh the challenges.

Additionally, the seemingly less-than-adequate state of professional development activities for invigilators in the UK and the advantages of self-directed professional development could lead to the conclusion that self-directed professional development is an appropriate and effective mode of development for examination invigilators. This is practically demonstrated later in this report where the author displays how he built workrelated knowledge in three important areas related to his practice as a senior examination invigilator.

\section{The connection between self-directed professional development and reflective Journaling}

Self-directed professional development, which is the development of practical and/or workrelated knowledge under the direction of the individual (Brown et al., 2001), can be enabled by the use of reflective journaling. Doucet and Wilson (1997), state that journaling is a means by which students can record and scrutinize their own learning experiences - to this statement could be added invigilators who can similarly scrutinize their own learning. It is this scrutiny of experiences and learning via reflective journaling that work-related knowledge can be developed. Moreover, reflective journaling is a tool, which enables the shifting of the responsibility for developing knowledge away from a preceptor and places this on the individual. In other words, it enables the development of self-directed autonomous professionals who take responsibility for their own professional learning (Calderhead, 1992). Also, the use of a reflective journal is a tool, which empowers and fosters a sense of discovery in its users (Clegg, 1997).

\section{Reflective journal analysis}

The use of Minott (2017) reflective approach to teaching practicum debriefing strategy reflective questions was used to guide the reflective journaling entries used in this report. Over the period of a week of examinations, information was gathered in response to the following questions: "What happened?" "What did you learn about invigilation?" And "What did you learn about 'self" as invigilator?" Minott (2017) refers to the three questions as "reflective" because they emerge from his understanding of reflective teaching, but, more importantly, they helped to encourage critical thinking about what is being observed or experienced. The questions used in this study encouraged the author to examine, not just the cognitive and the affective aspects of his practice, but to reflect on "self" as examination invigilator and leader.

Question 1 required only a description of the events that the author chose to record. The events recorded were ones he thought were important, of interest to him and required his full attention. He read through the responses to Questions 2 and 3 and found the ideas that recurred. These ideas and words became the main categories or themes (Creswell, 1998; Powell and Renner, 2003). For example, an examination of the responses to Question 2 and 3 revealed words and phrases such as being adaptable and flexible, "Thinking on your feet" and listening to others and correcting others. From these and other words and phrases emerged the theme of "humane leadership." From the process of analysis of the recorded events in the journal, the author built practical or work-related knowledge about critical aspects of the invigilation process in Further and Higher Education.

How exactly does reflective journaling enable the building of work-related knowledge? This is the focus of the next section of the paper, where the author critically discuss and 
display how he built work-related knowledge via reflective journaling about critical aspects of the invigilation process: adaptability/flexibility, leading humanely and "thinking on your feet"/reflection-in-action. Throughout this section, situations and events indicating his professional development are italicized for ease of reference.

Reflective journaling and building work-knowledge about adaptability/ flexibility

Journal entry April 29, 2019.

What happened? A student was placed in a personal examination area. A room by herself based on the college "well-being" department recommendation and information. The student complained that she wanted to be in the main examination hall with everyone else. I called the person in charge who moved the student to the main hall. I had to move all the stationery and equipment, which I had so nearly set out for use in the original room.

What was learned about invigilation? Organisers do make mistakes which invigilators have to deal with and respond to; for example, students' complaint and anger. The ability to communicate quickly with leadership (two-way radio) is invaluable.

What was learned about self as invigilator? I am able to adapt to changes and I am flexible.

Journal entry May 2, 2019.

What happened? A number of invigilators with some experience made up the team this morning and I had to lead. This was totally unexpected.

What was learned about invigilation? Sometimes invigilation requires the ability to work together with people with similar knowledge about the process and to lead them.

What was learned about self as invigilator? I can be on my P's and Q's. I can work well with other people with similar knowledge about the invigilation process. This requires the ability to be adaptable and to change.

A reflection on these two journal entries reveals both events required the ability to be adaptable/flexible. Entry 1 required the willingness to pack up and move to another room, which involved moving documentation, stationery and other equipment. Entry 2 required the willingness to accommodate and work with others with similar experience. The abovecited journal entries also reflect the authors' personal belief about working with others but, more importantly, they reinforced work-related knowledge regarding examination invigilation and leading such an endeavor. The knowledge reinforced includes the fact that 
to successfully engage the invigilation process requires adaptability/flexibility. This may include changing venues at short notice. This examination and outline of what was learned from both events is a part of the author's professional development, for Borthwick and Pierson (2008), made the point that professional development must include an examination and understanding of lessons learned from practice.

Reflective journaling and building work-knowledge about leading humanely The analysis of the reflective journal entries reveal aspects of leadership in regards to the examination invigilation process. It is, however, leadership that is influenced by compassion and sympathy for people, i.e. humane leadership.

Journal entry May 1, 2019.

What happened? A new invigilator was added to the team this afternoon; a student fell ill near the end of the session; a student caught cheating, notes written on his hand; students were impatient and wanted to leave before all exam scripts were collected by invigilators; had to correct the new invigilator on a number of occasions regarding the system of paper layout, collection, collation and on what student can and cannot do during the last or final 15 min of the examination and during the time the scripts were being collected.

What was learned about invigilation? This is a demanding role especially at the FE levels, especially where students are non-traditional, i.e. no GCSE or A level examination experience.

What was learned about self as invigilator? I do make mistakes but I am willing to not repeat them. I am willing to initiate new invigilator by being patient as they learn the paperwork processing.

In this entry, leading humanely is displayed in "correcting the new invigilator" and initiating him by being patient as he learned the "paperwork" processing carried out at the end of the examination.

Journal entry May 3, 2019.

What happened? A number of students wanted to take toilet breaks when it was not permitted to do so. I got to work with an invigilator with a very strong personality. One who seemed to have a "say" in every situation. On one occasion, I had to ask the invigilator to hold her thoughts for one minute as I discussed with another invigilator an issue that happened the previous day.

What was learned about invigilation? Leading requires the ability to look past personalities and see the individual. One will encounter a variety of individuals with different "quirks" and must lead them none-the-less.

What was learned about self as invigilator? I am a reflective senior invigilator, patient with subordinates with strong personalities, i.e. being too forceful and very opinionated. 
In this entry, leading humanely is displayed in being patient and accommodating with subordinates with strong personalities.

Journal entry April 29, 2019.

What happened? An invigilator shared with me an idea on how to improve and speed up the paper collection and collation process. I listened to it and gave the "go ahead"; I even said publicly to the invigilator that it was a great idea.

What was learned about invigilation? In large examinations, invigilation is a team event.

What was learned about self as invigilator? I am a leader open to suggestions from my subordinates and I am willing to implement these immediately. I not only listen to subordinates but acknowledge and implement their suggestions as appropriate.

In this entry, leading humanely is displayed in being open to suggestions from subordinates, acknowledging and implementing suggestions as appropriate.

Journal entry April 30, 2019.

What happened? Fewer students in this session. A much easier task. The team worked well together. I set out tasks and let the team get on with their individual assignments.

What was learned about invigilation? A team with members that get along makes the work enjoyable for all.

What was learned about self as invigilator? I can allow team members to work on their own initiative and to take the lead in areas.

In this entry, leading humanely is displayed in empowering team members, for example, allowing them to work on their own initiative and to take the lead in various areas.

A closer look at the entries above reveals the fact that engaging in reflective journaling facilitated the unearthing and naming of personal leadership style used in the examination invigilation process. By so doing the author reinforced the knowledge about the kind of leadership style that is applicable to the examination invigilation process, i.e. humane leadership. Further reflection on these entries also reinforced the idea that leading humanely can be displayed by senior invigilators and used in a number of ways throughout the invigilation process.

More importantly, this occurrence of being able to identify the kind of leadership that is useful in the examination invigilation process is indicative of a professional development exercise. This is so because doing so updated the author's work-related knowledge that will now enable him to further function effectively in his role as a senior examination invigilator (Speck and Knipe, 2005; Golding and Gray, 2006, and Harvey et al., 2005). This knowledge 
also boosts his personal confidence as a leader of examination invigilation teams. This occurrence of personal confidence boosting Villegas-Reimers (2003), defines broadly as professional development - with which Grootenboer (2009), agrees.

Reflective journaling and building work-knowledge about "thinking on your feet"/reflection-in-action

Examination invigilators rate "thinking on your feet"/reflection-in-action as relevant, very relevant and extremely relevant to their role. Its relevance is linked to its usefulness in various circumstances: decision making; preventing mistakes and uncovering students' duplicity (Minott, 2020).

The journal entries highlighted here required the ability to be organized in thinking and to be able to use team members equally and fairly, for example, in the collection and

Journal entry April 30, 2019.

What happened? This was a very busy and "packed house." A total of 98 students sat in a room doing various examinations. Examinations finished at different times, which required the use of small cards with information of "stop times" to be given to student whose examination finished first so as not to disturb by speaking aloud - other students with longer examination; cards were to be given in the last or final $15 \mathrm{~min}$ of the session and one at the end. I assigned team members various tasks on the spot. To compound all this, a student was found with unauthorised material and this had to be dealt with. This included filling in an examination misconduct form.

What was learned about invigilation? The whole process of invigilation and leading a team requires being organised. There is the need for organised thinking on the spot on how to use team members equally and fairly; for example, in the collection and collation process. I had to think about this on the spot and allocate invigilation accordingly. All these can be tiresome and mentally demanding. What was learned about self as invigilator? I am able to lead and, in the process, to be led by the ideas of those I lead. I have the ability to be organised, which is important, and also to follow policies. I was reminded of the need to look for details and be observant.

collation process and to do so by "thinking on your feet"/reflection-in-action. Bond (2011), researching school principals' ability to "think on their feet" made the point that the phrase simply describes the concept of reflection-in-action. This is thinking that occurs on the spot, in the thick of things, without the time to carefully analyze underlying factors of an event or situation. Schön (1987), likens this occurrence to a jazz musician who has to make up the music on the spot, i.e. improvise. The above-cited journal entries reinforced work-related knowledge regarding examination invigilation. The knowledge reinforced include the fact that to successfully engage the invigilation process requires the ability to "think on your feet"/reflect-in-action. This includes dealing fairly with all under your charge.

This examination of what was learned from the events is a part of one's professional development for Alsop (2000), points out advantages of self-directed professional 
Journal entry May 2, 2019.

What happened? The team was increased to five up from the normal three. I had to think on the spot how to allocate duties evenly.

What was learned about invigilation? It takes experience and the ability to think on your feet to lead a team of invigilators, allocate tasks equally and just to be a senior invigilator.

What was learned about self as invigilator? I am able to reflect-in-action and make the right decision and give clear instructions. For example, allocating closing tasks fairly to team members.

development when the writer states - among other things - it encourages a high standard of personal professional performance. This knowledge of the author's ability to think on his feet/reflect-in-action and how to engage this process has solidify his experience in this aspect of the examination invigilation process. This now allows him to improve personal efficacy as a senior invigilator (Alsop, ibid).

\section{Conclusion}

This self-study report has attempted to describe how, by employing reflective journaling during a week of examination invigilation, the author built or reinforced practical or workrelated knowledge relevant to critical aspects of his role as a senior examination invigilator. The ways portrayed in the study of how he achieved these may seem simplistic, for by simply reflecting on the events recorded in his reflective journal he gained knowledge. However, the process is anything but simple, for what is required is careful consideration, together with a process of disciplined intellectual criticism combining research, knowledge of context and balanced judgment (critical thinking) (Minott, 2009). This implies there is the need to "make the time" to accomplish this task and this requires a willingness to adopt an attitude of inquiry and engagement in selfassessment (Villegas-Reimers, 2003; Tigelaar et al., 2005). Achieving this is not without its challenges, given the fact that most busy professionals are saddled with numerous and varied tasks.

Although the study sought to promote self-directed professional development and the benefits of adopting this mode of development, some disadvantages are also addressed. For example, Craig (1999), states that it can be disadvantageous when an individual is not accustomed to being self-directed or is uncomfortable in setting and adhering to personal objectives and would prefer to be given instruction by an instructor and, additionally, may need the synergism of a group. It was argued that, given appropriate support, such an individual could be encouraged to see and appreciate the value of engaging in selfdirected professional development.

Finally, this is a self-study that critically discusses the personal experience of an individual senior examination invigilator in a further education context. What might be necessary is a much closer look at the long-term consequences of employing self-directed professional development, enacted through reflective journaling, on the development of individual invigilators and institutions. 


\section{References}

Alsop, A. (2000), Continuing Professional Development: A Guide for Therapists, Blackwell Science, Malden, MA.

Bezzina, C. and Camilleri, A. (2001), "The professional development of teachers in Malta", European Journal of Teacher Education, Vol. 24 No. 2, pp. 157-170.

Bond, J. (2011), "Thinking on your feet: principals", International Journal of Educational Leadership Preparation, Vol. 6 No. 4, available at: https://files.eric.ed.gov/fulltext/EJ974347.pdf

Borko, H. (2004), "Professional development and teacher learning: mapping the terrain", Educational Researcher, Vol. 33 No. 8, pp. 3-15.

Borthwick, A. and Pierson, M. (Eds) (2008), Transforming Classroom Practice: professional Development Strategies in Educational Technology, International Society for Technology in Education, Washington, DC.

Brown, D.L., Ferrill, M.J., Hinton, A.B. and Shek, A. (2001), "Self-directed professional development: the pursuit of affective learning", American Journal of Pharmaceutical Education, Vol. 65 No. 3, pp. 240-247.

Calderhead, J. (1992), "The role of reflection in learning to teach", in Linda, V. (Ed.) Reflective Teacher Education - Cases and Critiques, State University of New York, NY, pp. 139-146.

Chitpin, S. and Evers, C.W. (2005), "Teacher professional development as knowledge building: a Popperian analysis", Teachers and Teaching, Vol. 11 No. 4, pp. 419-433.

Clegg, S. (1997), "A case study of accredited training for research awards supervisors through reflective practice", Higher Education, Vol. 34 No. 4, pp. 483-498.

Craig, R. (Ed.) (1999), The ASTD Training and Development Handbook Guide to Human Resource Development, 4th ed., McGraw Hill, New York, NY.

Creswell, J.H. (1998), Qualitative Inquiry and Research Design: choosing among Five Traditions, Sage, London/New Delhi/Newbury Park, CA.

Doucet, C.R. and Wilson, S. (1997), "A three-step method of self-reflection using reflective journal writing", Journal of Advanced Nursing, Vol. 25, pp. 964-968.

Harvey, P., Sinclair, C. and Dowson, M. (2005), "Teacher motivation for postgraduate study: development of a psychometric scale for Christian higher education", Christian Higher Education, Vol. 4 No. 2, pp. 241-264.

Golding, L. and Gray, I. (Eds) (2006), Continuing Professional Development for Clinical Psychologists: A Practical Handbook, Blackwell, Oxford.

Grootenboer, P. (2009), "Self-directed teacher professional development", available at: www.aare.edu. au/99pap/gro99601.htm

Minott, M.A. (2009), Reflection and Reflective Teaching, a Case Study of Four Seasoned Teachers in the Cayman Islands, VDM Verlag Dr Müller Aktiengesellschaft and Co., Riga, Latvia, Germany, ISBN 978-3-639-15860-1.

Minott, M.A. (2017), 'A reflective approach to teaching practicum debriefing (RATPD)' paper back amazon.co.uk”, ISBN 10: 1978311494, ISBN-13: 978-1978311497, available at: www.amazon.com/ Reflective-Approach-Teaching-Practicum-Debriefing/dp/1978311494

Minott, M.A. (2018), "External examination invigilators' (EEIs) beliefs and inference about activities they consider important: Implication for examination policy", Journal of Perspectives in Applied Academic Practice, Vol. 6 No. 1, pp. 47-54.

Minott, M.A. (2020), "To what extent is 'thinking on your feet'/reflection-in-action relevant to the role of further and higher education examination invigilators? Implications for examination policy and practice", Journal of Perspectives in Applied Academic Practice, Vol. 7 No 2.

Powell, E.T. and Renner, M. (2003), "Analyzing qualitative data, university of Wisconsin-Extension USA", available at: https://learningstore.uwex.edu/Assets/pdfs/G3658-12.pdf 
Schön, D.A. (1987), Educating the Reflective Practitioner, Jossey-Bass, San Francisco, CA.

Shulman, L.S. and Shulman, J.H. (2004), "How and what teachers learn: a shifting perspective", Journal of Curriculum Studies, Vol. 36 No. 2, pp. 257-271.

Speck, M. and Knipe, C. (2005), "Why can't we get it right?", Designing High-Quality Professional Development for Standards-Based Schools, 2nd ed., Corwin Press, Thousand Oaks, CA.

Tigelaar, D., Dolmans, D., Grave, W., Wolfhagen, I. and Vleuten, C. (2005), "Participants' opinions on the usefulness of a teaching portfolio", Medical Education, Vol. 40 No. 4, pp. 371-378.

Villegas-Reimers, E. (2003), "Teacher professional development: an international review of literature", available at: http://unesdoc.unesco.org/images/0013/001330/133010e.pdf 